\title{
Coupled Ocean-Atmosphere Inter-Decadal Modes in the Tropics
}

\author{
By B.N. Goswami and Manu Anna Thomas \\ Center for Atmospheric and Oceanic Sciences, Indian Institute of Science, India
}

(Manuscript received 1 October 1999, in revised form 17 August 2000)

\begin{abstract}
Homogeneous upper air data for 50 years (1949-1998) from the National Centers for Environmental Prediction/National Center for Atmospheric Research (NCEP/NCAR) reanalysis project, sea surface temperatures and sea level pressure are used to bring out the three dimensional structure of two dominant decadal/multi-decadal variations in the tropics. The global three dimensional modes represent generalized forms of inter-decadal modes studied earlier only with surface data. In the vertical, both modes show approximate first baroclinic structures over the tropics. The Walker circulation associated with the multidecadal mode has a wavenumber two structure in the zonal direction. It is shown that the magnitude of major ascending and descending motions associated with the multi-decadal Hadley and Walker circulations, are comparable to those associated with the dominant inter-annual mode. Implications of these large scale global circulations associated with the low frequency oscillations in modulating regional climate on a inter-annual time scale are discussed.
\end{abstract}

\section{Introduction}

Due to the lack of consistent upper air data for a sufficiently long time, most studies addressing decadal/multi-decadal oscillations in the tropics so far have used mainly surface data (sea surface temperature (SST), sea level pressure (SLP), air temperature and surface winds) to bring out the surface and temporal characteristics of these oscillations. The three dimensional structure of the decadal/inter-decadal oscillations has been unknown. The characterization of the three dimensional structure of these oscillations is important for understanding the physical mechanisms responsible for them, as well as for understanding links between these oscillations and regional climate variability. For example, the ascending and descending branches of the Hadley and Walker circulations determine the climate of several tropical regions. The extent to which these low frequency variations modulate the tropical Hadley and the Walker circulation has also been unknown. With the availability of 50year data from the NCEP/NCAR reanalysis project, a homogeneous set of upper air data is now available to investigate the three dimensional structure of these modes.

The El Nino and Southern Oscillation (ENSO)-

Corresponding author: B.N. Goswami, Center for Atmospheric \& Oceanic Sciences, Indian Institute of Science, Bangalore 560012, India. E-mail: goswamy@caos.iisc.ernet.in (C) 2000, Meteorological Society of Japan like inter-decadal oscillation in the Pacific (Zhang et al. 1997; Kachi and Nitta 1997) and the Atlantic inter-hemispheric dipole mode (Moura and Shukla 1981; Servain 1991; Carton et al. 1996) are two important modes of climate variability in the tropics and sub-tropics identified earlier from surface data with decadal/multi-decadal time scales. The spatial structure of the ENSO-like inter-decadal mode in sea surface temperatures (SST) bears some similarity with that of its inter-annual counterpart (Zhang et al. 1997; hereafter referred as ZWB) having SST anomalies in the eastern tropical $\mathrm{Pa}$ cific that is less equatorially confined than that of inter-annual ENSO and having large SST anomalies of opposite sign in the north Central Pacific. The Atlantic dipole involves spatially coherent SST variations in either hemisphere between $5^{\circ} \mathrm{N}-20^{\circ} \mathrm{N}$ and $5^{\circ} \mathrm{S}-15^{\circ} \mathrm{S}$. Anomalies usually appear with opposite sign in each hemisphere although the development is not always simultaneous. There is some debate (Houghton and Tourre 1992; Mehta 1998) over whether the northern and the southern components are dynamically related. The ENSO-like interdecadal oscillation influences the climate of northern America through modification of the statistics of the PNA pattern (Trenberth and Hurrell 1994), while the Atlantic dipole is known to influence the rainfall over parts of South America and Sahelian rainfall (Moura and Shukla 1981). It is not clear whether, they represent independent modes of variability of the global tropical coupled ocean-atmosphere sys- 
tem. In the present study, using the upper air data in conjunction with SST and SLP data and by carrying out a combined empirical orthogonal function (CEOF) analysis, we identify the three dimensional structure of two dominant coupled decadal modes in the global tropics. While the spatial structure of the two dominant decadal modes bears some similarity with the ENSO-like inter-decadal mode in the Pacific, and the dipole mode in the Atlantic respectively, these modes are associated with significant anomalies in the other basins as well and probably represent two more fundamental forms of decadal/multi-decadal oscillations in the global tropics. The Hadley and Walker circulations associated with the dominant decadal modes are also brought out and compared with those associated with the dominant inter-annual mode namely, the ENSO mode.

\section{Data sets used}

The circulation data used in this study are the products of the NCEP/NCAR reanalysis project (see Kalnay et al. 1996 for details) that is based on a frozen state-of-the-art global data assimilation system that includes a T62 forecast model, and a data base as complete as possible. Due to the fact that the analysis system and the model remain unchanged throughout the analysis period, the reanalyzed data is expected to be devoid of any artificial climate jumps. We obtained monthly mean winds and vertical pressure velocity at a number of pressure levels and velocity potential at $200 \mathrm{hPa}$ for the period January 1949 to December 1998. For sea level pressure data we have used the GMSLP2 data set developed by the U. K. Meteorological Office (Bassnett and Parker 1997). This data set consists of gridded monthly SLP data covering the period 1871-1995, and has been compiled by blending a combination of existing mean sea level pressure analyses with marine and land observations using a Laplacian interpolation technique.

The sea surface temperature data is taken from the Comprehensive Ocean Atmosphere Data Set (COADS, Woodruff et al. 1987) for the period 1949 to 1989 . For the period 1989 to 1998 the SST data is taken from the Optimum Interpolation SST data set (OISST) (Reynolds and Smith 1994). Both data sets are at 2 degrees latitude by 2 degrees longitude resolution. Climatological SST is calculated separately for the COADS and OISST and monthly anomalies are calculated with respect to their individual climatologies. The anomalies of the two data sets are then merged to obtain a anomaly data set from 1949 to 1998. Monthly anomalies of the circulation data, as well as that of the SLP data, are also calculated by removing the climatological annual cycle. The climatological annual cycle is calculated using the full length of the record. The decadal/multi-decadal variations are separated from inter-annual and higher frequency variations using a harmonic analysis. The interannual and higher frequency variations are reconstructed from all the modes with period less than 7 years, while the decadal/multi-decadal component is reconstructed from all the modes with period larger than 7 years. The decadal component will also be referred to as the low-pass (LP) filtered component and may contain any trend the data contains. Similarly, the inter-annual component will also be referred to as the high-pass (HP) filtered component. Two leading modes of decadal/multi-decadal variability are identified using a combined empirical orthogonal function (CEOF) analysis of several fields. The identity and fundamental character of the two decadal/multi-decadal modes obtained from CEOF analysis are further tested with a data set covering a much longer period. For this purpose, we use the global analysis of SST for the period 1871-1991 created by Kaplan et al. (1997) at the Lamont-Doherty Earth Observatory. This analysis is based on the application of reduced space optimal estimation to the global SST anomalies. Combining anomalies from OISST data from 1992 to 1998 with this data set, the decadal component is separated in the same manner described earlier.

\section{Results}

\subsection{Structure of decadal/multi-decadal modes}

Recent studies (White et al. 1997; White and Cayan 1998) have identified two major sub-ENSO modes of variability in the global SST and SLP, one decadal mode (8-13 years) and another multidecadal mode (15-35 years) in addition to a trend. Before we attempt to isolate the coupled decadal/multi-decadal modes, we examine the characteristic time scales associated with the ENSO-like inter-decadal variation and the Atlantic dipole variation. An equatorial Pacific decadal index (EQPAC) is defined as low pass filtered SST anomalies averaged over the NINO3 $\left(150^{\circ} \mathrm{W}-90^{\circ} \mathrm{W}, 5^{\circ} \mathrm{S}-\right.$ $5^{\circ} \mathrm{N}$ ) area. An Atlantic dipole variability (ADV) is defined as the difference between low pass filtered SST anomalies averaged over $45^{\circ} \mathrm{W}-35^{\circ} \mathrm{W}, 10^{\circ} \mathrm{N}-$ $20^{\circ} \mathrm{N}$ and $15^{\circ} \mathrm{W}-5^{\circ} \mathrm{W}, 20^{\circ} \mathrm{S}-10^{\circ} \mathrm{S}$. These two indices calculated from low pass filtered SST from 18711998 are shown in Fig. 1a and their spectra are shown in Fig. 1b. Both time series have a trend, but the Atlantic dipole index is basically dominated by a decadal oscillation ( $\sim 12$ years) while the EQPAC low frequency variations have both the decadal ( $\sim 12$ years) and inter-decadal ( $\sim 22$ years) oscillations. The ENSO-like inter-decadal variability in the Pacific studied earlier with surface data (e.g., Zhang et al. 1997) contains both these time scales of variations.

To study the dominant modes of the low-pass fil- 

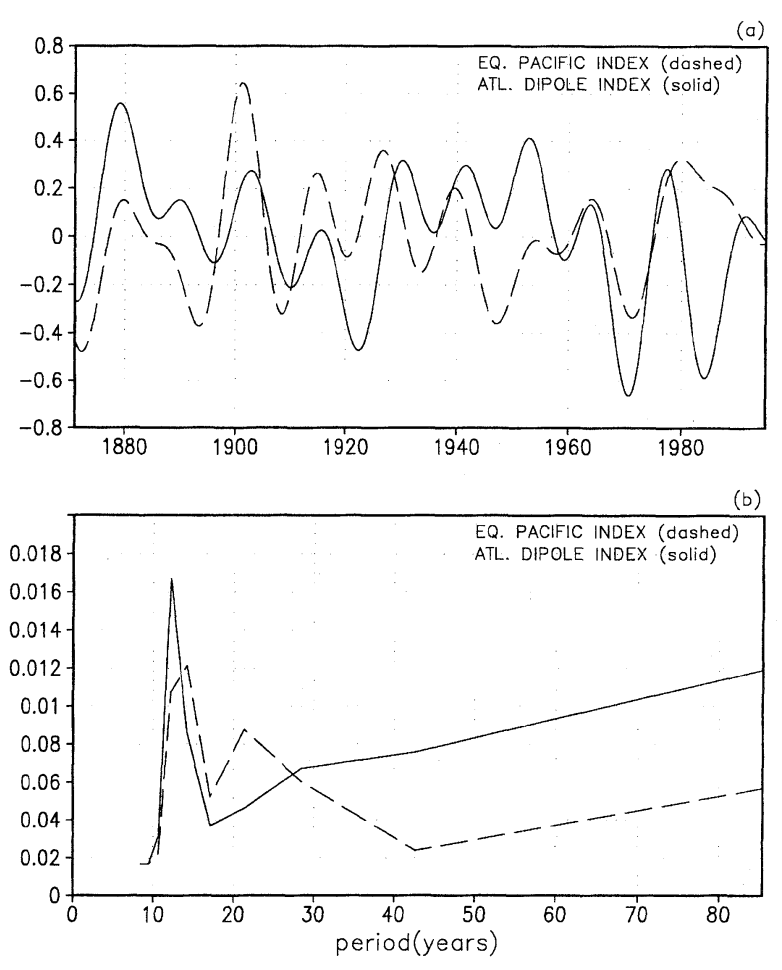

Fig. 1. (a) Time series of LP filtered SST (deg C) associated with the Atlantic dipole index (ADI, solid) and an index of equatorial Pacific decadal variability (EQPAC, dashed). (b) Spectra of ADI and EQPAC.

tered fields, empirical orthogonal function (EOF) analysis of individual fields were carried out in the global domain between $40^{\circ} \mathrm{S}$ and $60^{\circ} \mathrm{N}$. Since our SLP data were only up to 1995 , the period of CEOF analysis was restricted to be between 1949 and 1995. The first two EOFs of the low-pass filtered fields together explain $60-70 \%$ of the total low-pass filtered variance. The fact that the two EOFs of all the circulation fields, and those of SST are strongly related to each other (Table 1) indicates that the two modes represent two coupled modes of the oceanatmosphere system. With this background, a combined EOF (CEOF) analysis (Nigam and Shen 1993) was carried out with SST, SLP, winds at $850 \mathrm{hPa}$, winds at $200 \mathrm{hPa}$ and velocity potential at $200 \mathrm{hPa}$, where each field was normalized by its own area averaged temporal variance. To be able to calculate the CEOFs with seven fields in the global domain between $40^{\circ} \mathrm{S}$ and $60^{\circ} \mathrm{N}$, we averaged the fields over $5^{\circ}$ Lat. by $10^{\circ} \mathrm{Lon}$. boxes. The first ten eigen values corresponding to the first ten CEOFs are shown in Fig. 2 expressed as a percentage of the total variance. According to the test suggested by North et al. (1982), the first two eigen vectors appear to be statistically separable from sampling errors. The PCs of the leading CEOFs are shown in Fig. 3.

The two PCs appear to represent two indepen- dent modes of oscillation of the coupled system. Although the time span of 50 years does not allow us to determine quantitative spectral characteristics of the two PCs, it is clear that PC1 represents the trend and the lower frequency interdecadal component while $\mathrm{PC} 2$ represents the shorter period decadal component. The characteristic time scales associated with the first two EOFs, therefore, indicate that they may be representative of the ENSO-like inter-decadal oscillation and the Atlantic dipole mode respectively. The first $\mathrm{PC}$ is similar to the PC of the dominant mode of LP filtered SST obtained by ZWB (their Fig. 3). The main difference is that the peak around 1960 in our PC1 remains above the zero line. This difference is likely to be due to the fact that theirs was based on an EOF analysis over the Pacific basin only while ours is from a global CEOF analysis. We were able to reproduce $\mathrm{PC} 1$ of $\mathrm{ZWB}$ when a CEOF was carried out on the Pacific domain only. The difference between our PC1 and that of Kachi and Nitta (1997) is due to the fact that they removed a linear trend from their data while we did not.

To illustrate the SST pattern associated with the two dominant CEOFs, correlations between the PC1 and PC2 and high resolution LP filtered SST are carried out and shown in Figs. 4a and 4b. The SST pattern associated with CEOF1 (the inter-decadal mode) has strong out of phase variability between the north Central Pacific and eastern tropical $\mathrm{Pa}$ cific. It is also associated with strong coherent variability in the tropical Indian Ocean in phase with the eastern tropical Pacific. The Atlantic variability associated with this mode is characterized by fluctuations with the same sign over most of the tropical region. In the Pacific, the SST CEOF1 has large loadings in the sub-tropical eastern Pacific and equatorial western Pacific. The SST pattern associated with the CEOF1 is similar in some ways with that associated with the LP filtered SST mode described by ZWB. Much larger SST loadings in the Indian Ocean in our CEOF1 as compared to the the ENSOlike inter-decadal variability described by ZWB represent major differences between the two. We also note that CEOF1 is associated with large SST loadings in the southern tropical Atlantic. An examination of time series of low frequency (LF) SST in the southern tropical Atlantic and Indian Ocean shows that both locations are dominated by trend and multi-decadal oscillations. Therefore, CEOF1 essentially separates the patterns associated with trend and multi-decadal variability.

On the other hand, the SST pattern associated with the CEOF2 (Fig. 4b) is characterized by a dipole structure around the equator in the tropical Atlantic. It is also associated with ENSO-like SST anomalies around the equator in the eastern Pacific surrounded by a horse-shoe type pattern of anoma- 
Table 1. Cross correlation between the PC1 [PC2] of the dominant EOFs of different variables.

\begin{tabular}{||l|c|c|c|c|c||}
\hline VARIABLES & U200 & V200 & U850 & V850 & SST \\
\hline U200 & 1 & & & & \\
\hline V200 & $0.98[0.82]$ & 1 & & & \\
\hline U850 & $0.95[0.87]$ & $0.96[0.85]$ & 1 & & \\
\hline V850 & $0.92[0.78]$ & $0.92[0.82]$ & $0.96[0.87]$ & 1 & \\
\hline SST & $0.84[0.57]$ & $0.79[0.47]$ & $0.76[0.60]$ & $0.81[0.73]$ & 1 \\
\hline
\end{tabular}

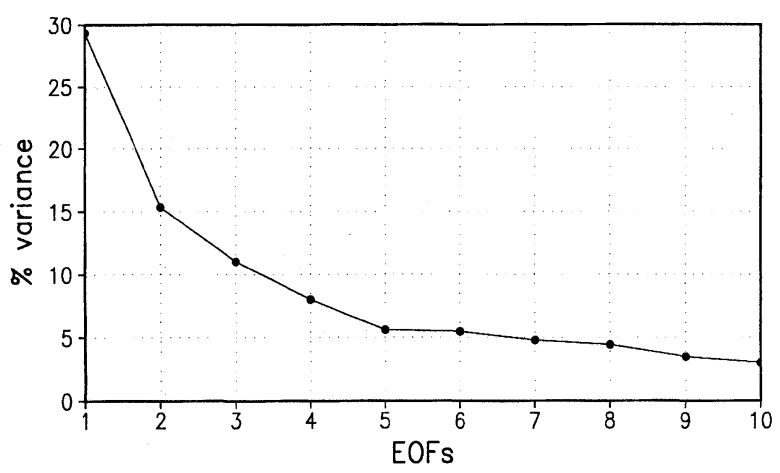

Fig. 2. Eigen values corresponding to the first $10 \mathrm{CEOFs}$.

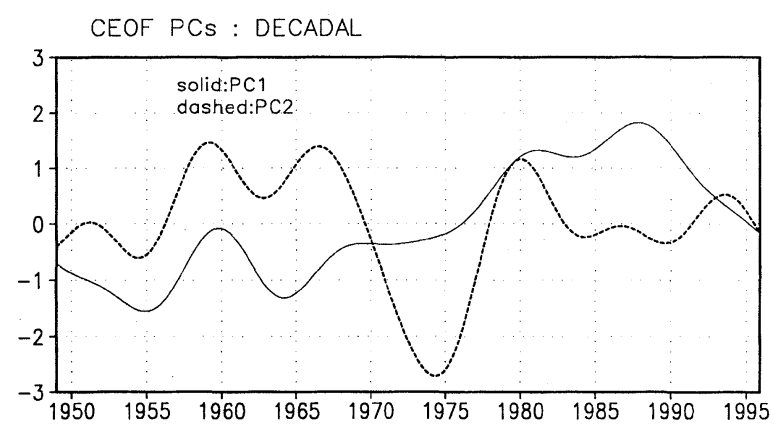

Fig. 3. Principal component(PC) time series of the first two decadal CEOFs normalized by their own temporal standard deviation $(92.98,66.96$ respectively). A major transition of $\mathrm{PC} 1$ around 1976 is noteworthy.

lies of opposite sign. The anomalies in the Indian Ocean associated with this mode are weak and vary out of phase with those in the equatorial eastern $\mathrm{Pa}$ cific. The SST pattern associated with this mode in the tropical Atlantic indicates that this mode represents the ADV. This conjecture is supported by the fact that the correlation between PC2 and Atlantic dipole index (ADI) is 0.6 and is statistically significant at $99.9 \%$ level. Moreover, the correlation pattern between ADI and decadal SST for the pe- (a)

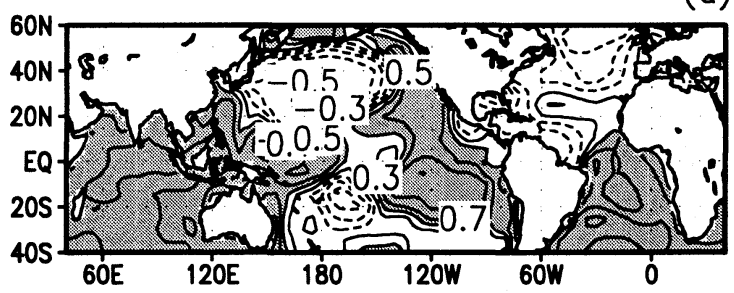

(b)

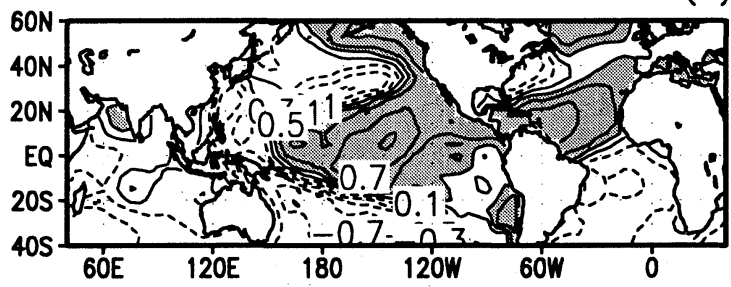

(c)

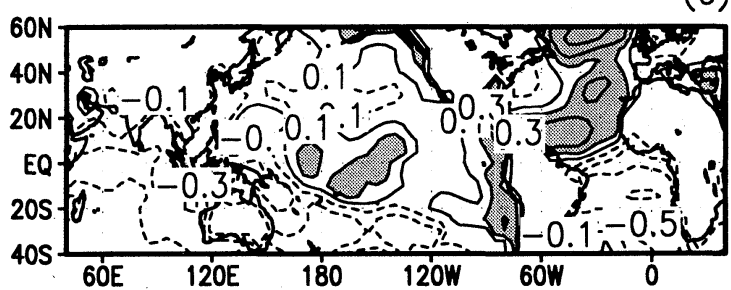

Fig. 4. (a) Correlation of low pass filtered SST with PC1 associated with CEOF1. The minimum contours are \pm 0.1 and contour interval is 0.2 . The correlation values greater than +0.3 are shaded. (b) Same as Fig. 4a but for SST correlation with PC2 associated with CEOF2. (c) Same as in Fig. 4a but with Atlantic dipole index.

riod 1871-1998 (Fig. 4c) has a good deal of similarity with that associated with PC2 (Fig. 4b), the pattern correlation between them being 0.66 . In the Pacific, this mode is associated with large SST loadings in the central equatorial Pacific. Examination of ADV as well as LP filtered SST in the central equatorial Pacific show that both are dominated by decadal (12-14 years) variations. The CEOF2 essentially 
represents the pattern of variability associated with the decadal mode. In the Pacific, the two EOFs represent variability in the two time scales associated with the so called 'ENSO-like inter-decadal' variability studied earlier (ZWB). Our analysis shows that a part of 'ENSO-like' LF variability in the tropical Pacific vary concurrently with the dipole type variability in the tropical Atlantic.

The spatial patterns of SLP, winds at $200 \mathrm{hPa}$ and $850 \mathrm{hPa}$ and velocity potential at $200 \mathrm{hPa}$ associated with the first CEOF are shown in Fig. 5, while the same fields associated with the second CEOF are shown in Fig. 6. The SLP pattern associated with the first CEOF (Fig. 5) is similar to that of the ENSO-like inter-decadal oscillation obtained earlier from surface data (Kachi and Nitta 1997; Zhang et al. 1997). The other important feature to note of the three dimensional structure is the wave number two structure seen in SLP and the velocity potential field at $200 \mathrm{hPa}$. It represents an anomalous Walker circulation with descending motion between $120^{\circ} \mathrm{E}$ and $130^{\circ} \mathrm{W}$ and ascending motions between $90^{\circ} \mathrm{W}$ and $30^{\circ} \mathrm{W}$. Low level winds show convergence to warm SST anomalies in the eastern equatorial Pacific and eastern Indian Ocean. The winds at $850 \mathrm{hPa}$ are out of phase with that at $200 \mathrm{hPa}$ in most of the tropics. Thus, this mode has an approximate first baroclinic vertical structure. The structure of the dominant multi-decadal mode indicates that it is forced by convective heating anomalies arising from associated tropical SST anomalies. Like the first CEOF, the second CEOF is also characterized by an approximate first baroclinic vertical structure in the tropics. The upper level circulation is characterized by an anti-cyclonic pair straddling the equator in the central and eastern Pacific. The SLP and velocity potential fields indicate that the second dominant mode is also associated with a divergent circulation in the east-west with a wave number two structure. However, a closer scrutiny shows (and will be more clearly illustrated later) that it is associated with one major east-west cell with ascending motion centered around $160^{\circ} \mathrm{W}$ and descending motion centered around $60^{\circ} \mathrm{W}$. The divergence circulation (e.g., gradient of the velocity potential) elsewhere is rather weak.

The structure of the dominant inter-annual mode is obtained by conducting a CEOF analysis of the inter-annual anomaly (HP filtered) fields. The first CEOF shows (Fig. 7) the canonical structure of the inter-annual ENSO mode. The inter-annual ENSO mode is statistically independent with the ENSOlike inter-decadal mode as is borne out by the correlation between the inter-annual PC1 (top panel of Fig. 7), and inter-decadal PC1 (Fig. 3a) being nearly zero. The Southern Oscillation pattern in the SLP, a wave number one pattern for the Walker circulation, two anti-cyclones at upper atmosphere in the cen-
CEOF $1-D E C[30 \%]$
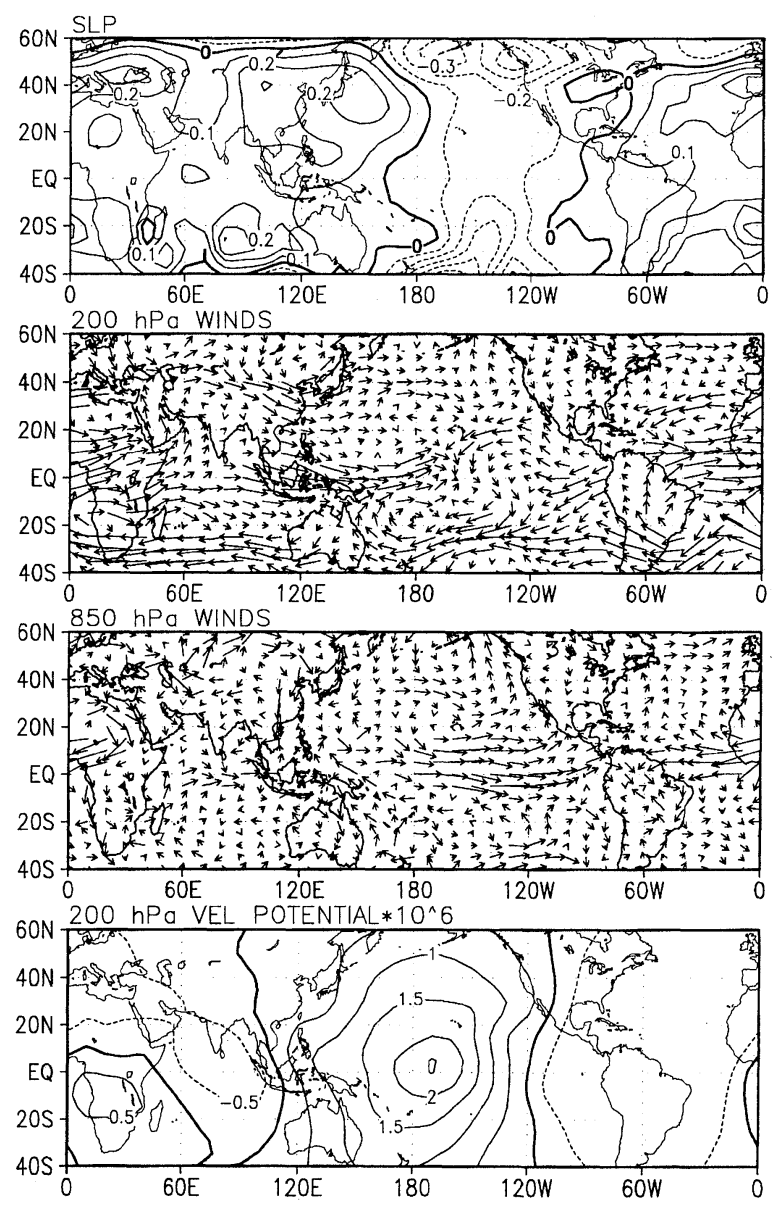

Fig. 5. Spatial patterns of $\operatorname{SLP}(\mathrm{hPa})$, $200 \mathrm{hPa}$ winds $\left(\mathrm{ms}^{-1}\right), 850 \mathrm{hPa}$ winds $\left(\mathrm{ms}^{-1}\right)$ and velocity potential at $200 \mathrm{hPa}\left(\mathrm{s}^{-1}\right)$ associated with decadal CEOF1. For $200 \mathrm{hPa}$ winds, 0.2 inches of arrow length correspond to $3 \mathrm{~ms}^{-1}$ and for $850 \mathrm{hPa}$ winds, 0.25 inches of arrow length correspond to $2 \mathrm{~ms}^{-1}$.

tral and eastern Pacific girdling the equator, and low level convergence at the equator in the central and eastern Pacific, characteristic of the ENSO mode are seen. Both the inter-annual and inter-decadal ENSO modes appear to have a first baroclinic vertical structure in the equatorial region.

To bring out the three dimensional structure of the divergent circulation associated with the two dominant decadal/multi-decadal modes more clearly, regression of LP filtered zonal, meridional and vertical pressure velocities on $\mathrm{PC} 1$ and $\mathrm{PC} 2$ of CEOF are calculated at all levels. The Walker circulation associated with each mode is described as vectors of zonal wind regression and vertical pressure velocity regression (taken with a negative sign) averaged over $10^{\circ} \mathrm{S}$ and $10^{\circ} \mathrm{N}$. The Walker circulation associated with the inter-decadal (EOF1) and the decadal (EOF2) modes are shown in Figs. 8a and 8b. 
CEOF2-DEC[15\%]
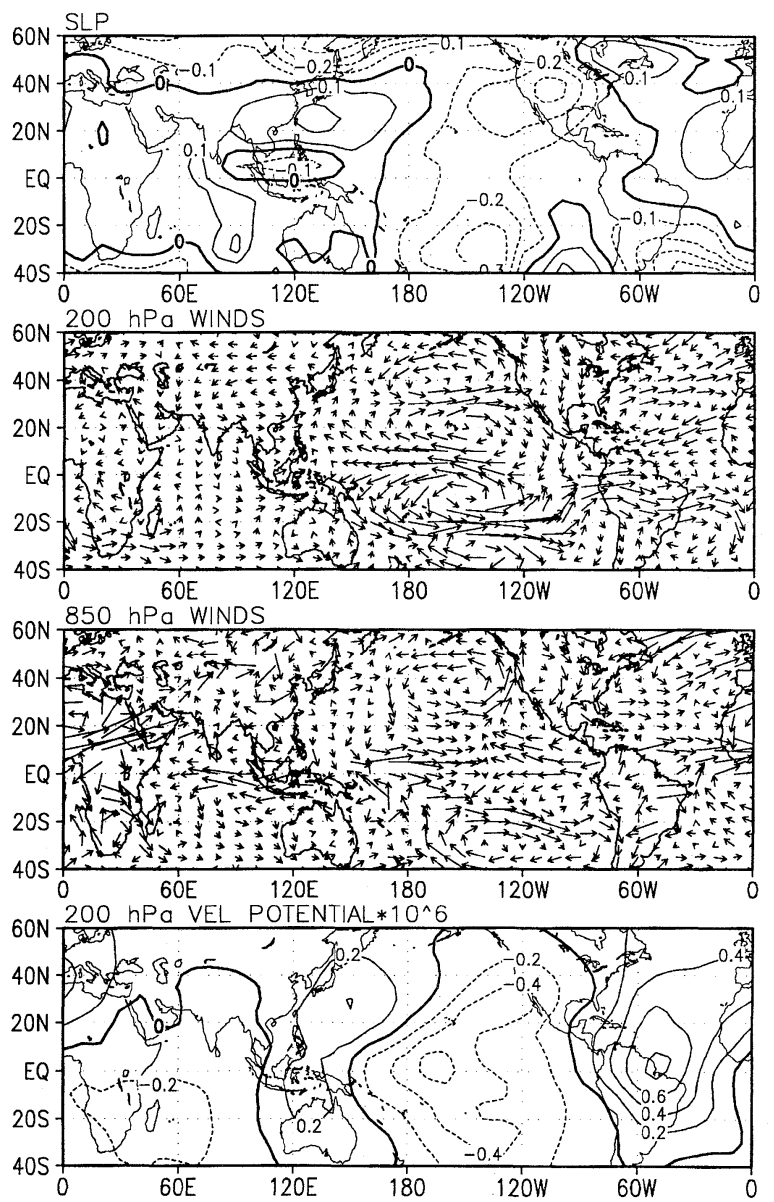

Fig. 6. Same as Fig. 5 but for decadal CEOF2. For $200 \mathrm{hPa}$ winds, 0.25 inches of arrow length correspond to $3 \mathrm{~ms}^{-1}$ and for $850 \mathrm{hPa}$ winds, 0.25 inches of arrow length correspond to $1 \mathrm{~ms}^{-1}$.

The shaded regions in the upper and lower panel represents regressions significant at $95 \%$ and $90 \%$ confidence levels respectively estimated using a two tailed t-test. Similarly, Walker circulation associated with the dominant inter-annual mode (PC1 of residual CEOF) is shown in Fig. 8c. The Walker circulation associated with the dominant inter-annual mode is significant at $95 \%$ level everywhere. Hence it is not shaded. The major cell of ascending and descending motion associated with the first and second modes are located approximately at the same regions, but have opposite signs. Therefore, when the two modes are out of phase, they tend to enhance the east-west circulation in this region. We note from Fig. 3 that for most of the period (e.g., between 1955 and 1970 and between 1980 and 1990) PC1 and PC2 are out of phase. During these periods, both modes would tend to enhance or weaken the anomalous Walker circulation in the Central Pacific and northern South America. Only between 1970 and 1980 the divergent circulation is dominated
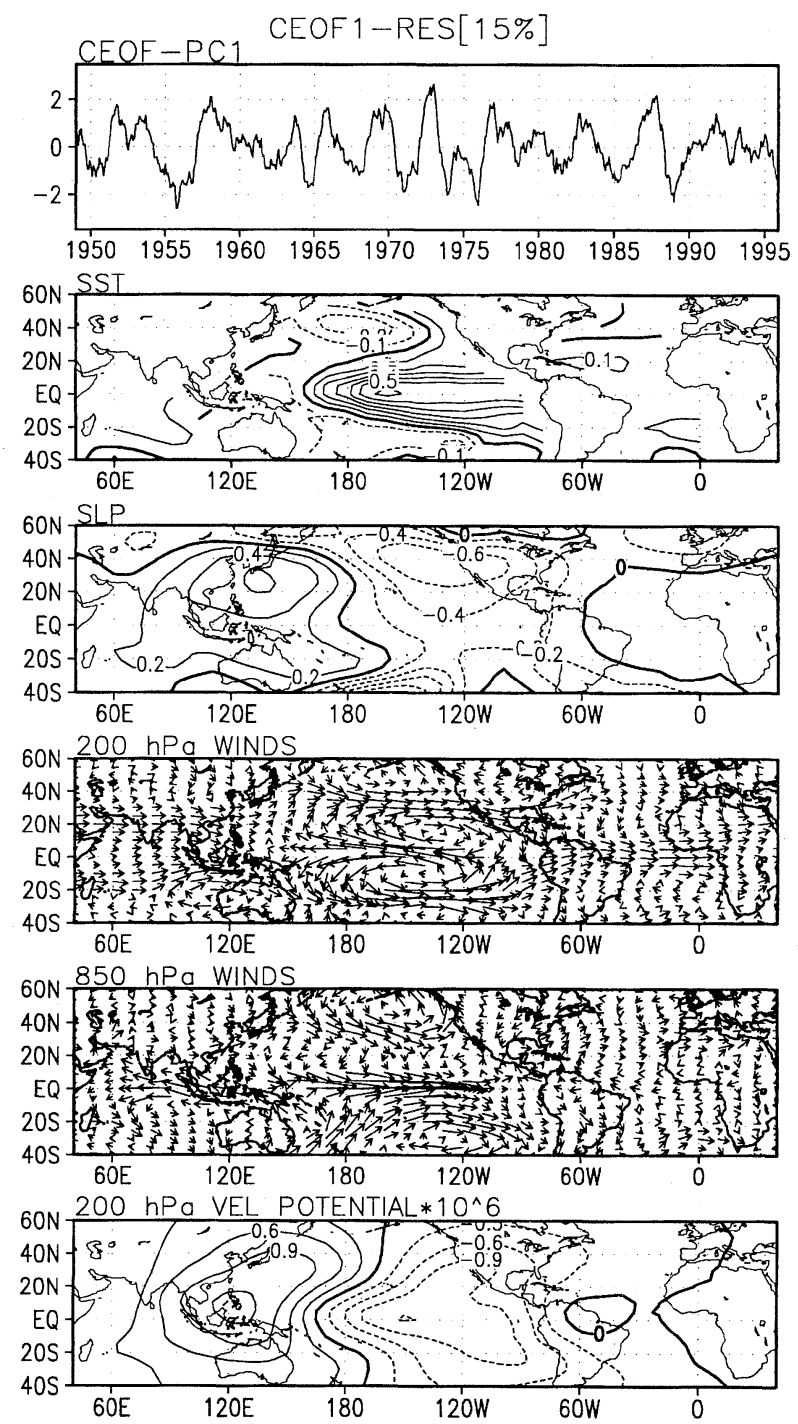

Fig. 7. Same as Fig. 6 but for inter-annual CEOF1. For $200 \mathrm{hPa}$ winds, 0.25 inches of arrow length correspond to $4 \mathrm{~ms}^{-1}$ and for $850 \mathrm{hPa}$ winds, 0.35 inches of arrow length correspond to $2 \mathrm{~ms}^{-1}$.

by the second mode as the first mode goes through a transition and does not make significant contribution. As a result, it may be sufficient to compare the Walker circulation associated with CEOF1 with that associated with inter-annual mode. We note that there are differences between the major locations of ascending/descending branches associated with the decadal mode and inter-annual mode. While the divergent circulation associated with the decadal mode tends to oppose that associated with the inter-annual mode in the central Pacific and northern South America, they tend to reinforce each other over the eastern Pacific, the western Pacific and the eastern Indian Ocean. 
WALKER CIRCULATION DECADAL PC
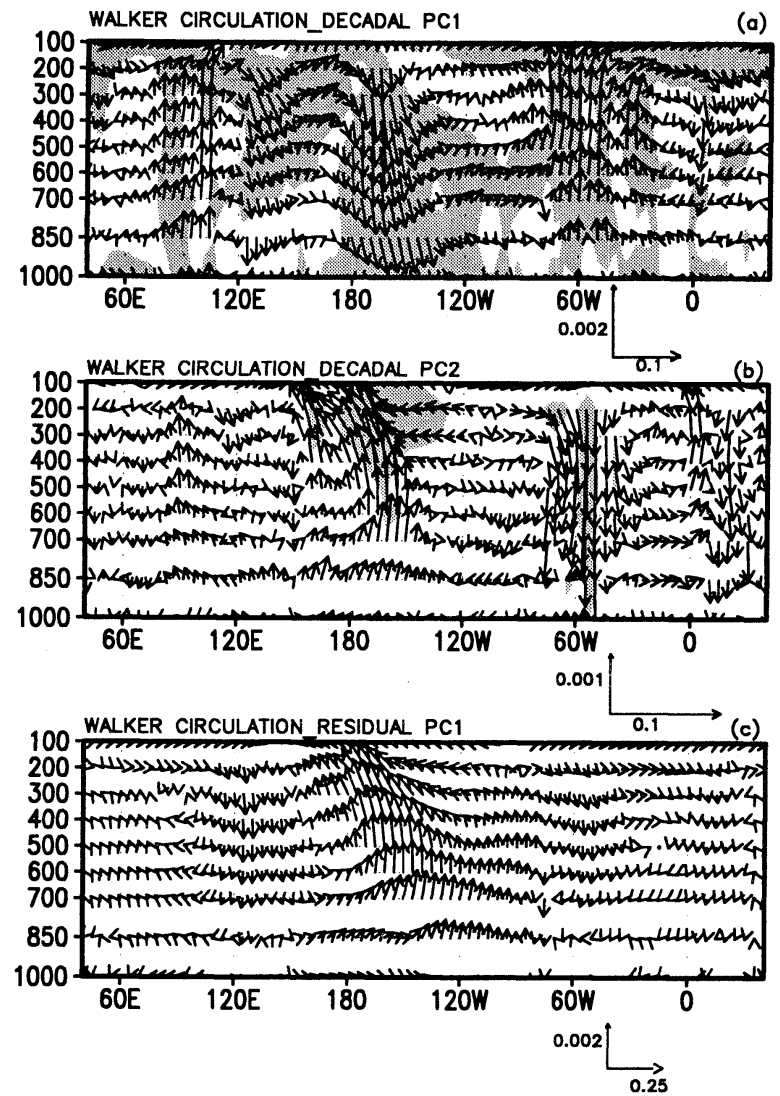

Fig. 8. (a) Walker circulation associated with the dominant decadal mode. Vectors are plotted with regression of zonal wind and vertical pressure velocity (taken with a negative sign) on PC1 averaged between $10^{\circ} \mathrm{S}$ and $10^{\circ} \mathrm{N}$. Shading indicates regions where regressions are significant at $95 \%$ level. (b) Same as (a) but associated with PC2. Shading represents significance at $90 \%$ level. (c) Walker circulation associated with the inter-annual variations. Vectors are plotted with regression of residual zonal wind and vertical pressure velocity on $\mathrm{PC} 1$ of $\mathrm{CEOF}$ of residual fields. In this case all regressions are significant at $95 \%$ due to higher degrees of freedom.

\subsection{Combined effect of the decadal/multi-decadal modes on tropical climate}

As noted in the previous section the east-west circulation associated with the two decadal/multidecadal modes are similar and for most of the time they reinforce each other. Therefore, in this section we shall examine the combined effect of the two decadal/multi-decadal modes on the tropical climate.

The regional climate in the tropics is affected by the location and strength of ascending and descending branches of the resultant Walker circulation (as a superposition of the inter-annual and decadal/multidecadal components). Whether the decadal/multi- decadal Walker circulation would be able to modulate the inter-annual one, would depend on the relative strengths of the two circulations. In the previous section, we have shown the similarity and difference between the Walker circulation associated with the decadal/multi-decadal modes and interannual variability. However, a quantitative estimate of relative strengths was not made. To estimate the relative strength of the two Walker cells, composites corresponding to all 'warm' minus 'cold' phases of the inter-annual circulation (HP filtered anomalies) and the multi-decadal circulation (LP filtered anomalies) are calculated. The inter-annual 'warm' composite is based on an average of nine El Nino events while the 'cold' composite is based on seven La Nina events within the period under consideration. As the dominant multi-decadal mode has only one 'cold' and one 'warm' phase during the period under consideration (PC1, Fig. 3), the dominant multi-decadal variations is represented by a difference between a 'warm' and a 'cold' composites constructed by averaging of five consecutive years (1982-1987) and (1962-1967) in the two periods respectively. Such composites include contributions from both decadal/multi-decadal modes described earlier. The Walker circulation is represented by vector wind formed with pressure vertical velocity (taken with a negative sign) and zonal winds at a number of vertical levels averaged between $\left(10^{\circ} \mathrm{S}-\right.$ $\left.10^{\circ} \mathrm{N}\right)$. Mass flux stream function $\left(\psi_{w}\right)$ in units of $10^{10} \mathrm{~kg} / \mathrm{s}$ is also calculated by vertically integrating the observed zonal winds, $(\bar{u})$ averaged over the equatorial belt between $5^{\circ} \mathrm{S}$ and $5^{\circ} \mathrm{N}$.

$$
\psi_{w}=-\frac{R}{g} \int_{o}^{p}(\bar{u}) d p
$$

The sign convention for $\psi_{w}$ is fixed using the following consideration. Positive (negative) longitudinal gradient of $\psi_{w}$ is assumed to be proportional to negative (positive) pressure vertical velocity or ascending (descending) motion. The vectors showing the east-west circulation together with associated mass fluxes are shown in Fig. 9. As expected the structure of the east-west Walker circulation is similar to the regression pattern on PC1 (Fig. 8a).

The new information in Fig. 9 are the mass fluxes associated with the decadal/multi-decadal variations and the inter-annual ENSO variability. A rather striking feature is that the mass fluxes associated with the decadal/multi-decadal variation are quite comparable to those associated with the inter-annual ENSO variations. The maximum mass flux in the decadal Walker circulation varies between $6 \times 10^{10} \mathrm{~kg} / \mathrm{s}$ and $-8 \times 10^{10} \mathrm{~kg} / \mathrm{s}$ while that associated with inter-annual variations ranges from $6 \times 10^{10} \mathrm{~kg} / \mathrm{s}$ and $-9 \times 10^{10} \mathrm{~kg} / \mathrm{s}$. This conclusion was also supported by examination of vertical pressure velocity and zonal wind anomalies associated 
WALKER CIRCULATION(DJF)
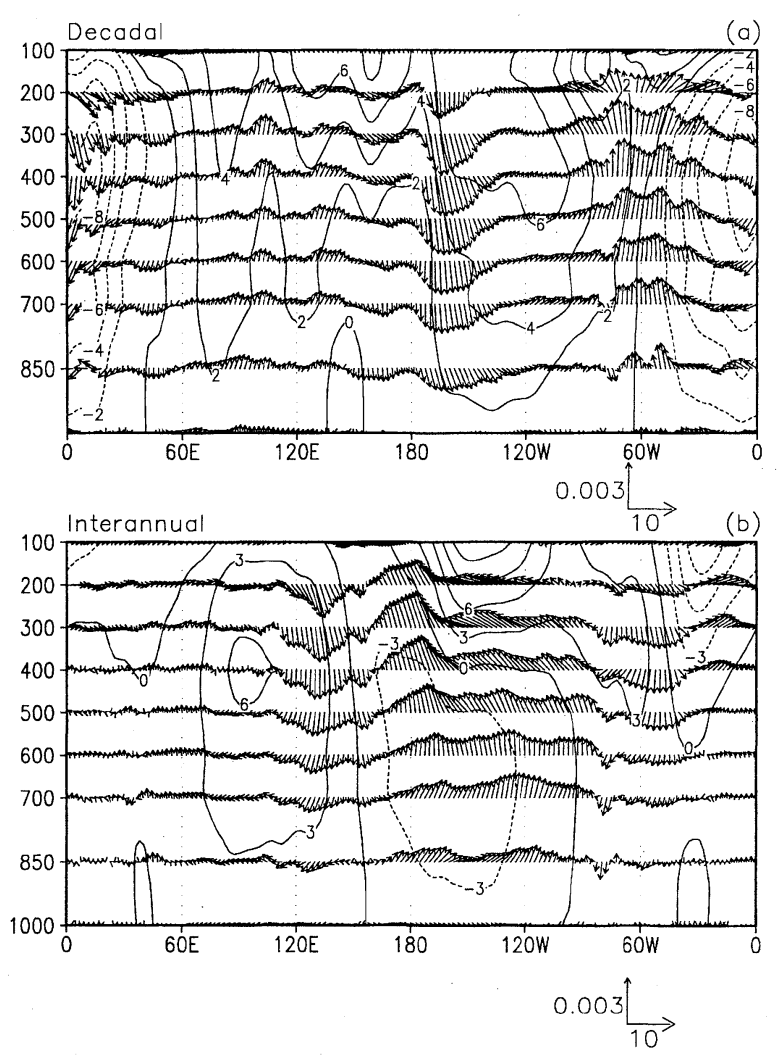

Fig. 9. (a) Boreal winter (DJF) ('warm''cold') composite Walker circulation averaged over $10^{\circ} \mathrm{S}$ and $10^{\circ} \mathrm{N}$ associated with the multi-decadal mode. Vector winds are constructed with pressure vertical velocity (taken with a negative sign) and zonal velocity. Unit vector for vertical velocities corresponds to $0.003 \mathrm{hPas}^{-1}$. The contours represent the mass flux stream function in $10^{10} \mathrm{kgs}^{-1}$. (b) Same as in (a) but for the (El Nino-La Nina) composite for the inter-annual mode. The El Nino and La Nina years used in generating this inter-annual composite are 1963, 1965, 1969, 1972, 1976, 1982, 1987, 1992, 1997 and $1964,1968,1971,1973,1983,1988$, 1996 respectively. Unit vector for vertical velocities correspond to $0.003 \mathrm{hPas}^{-1}$.

with the decadal and inter-annual variations (not shown). Thus, the decadal variations are likely to modulate the inter-annual variations in a significant manner. For example, in a warm decadal phase, during an El Nino, there will be enhanced ascending motion over the eastern Pacific and Indonesian region but the decadal motions would oppose and neutralize inter-annual ascending motion in the central $\mathrm{Pa}$ cific $\left(160^{\circ} \mathrm{E}-160^{\circ} \mathrm{W}\right)$, and enhance descending motion over the western Pacific. In the same decadal phase, during a La Nina, the inter-annual circulation would be generally enhanced by the decadal one except over the eastern Pacific where large descending motion due to La Nina will be opposed and neutralized by ascending motions associated with the decadal mode. During a cold decadal phase, the Walker circulation associated with El Nino will be enhanced by the decadal circulation while that associated with La Nina will be weakened.

Similarly, the tropical Hadley circulation associated with the dominant inter-decadal mode is compared with that associated with the dominant interannual mode. The boreal winter (DJF) ('warm''cold') decadal composites are shown in Fig. 10a. The wind vectors indicating the meridional circulation for these composites shown in the figure are constructed with zonally averaged pressure velocity $(\omega)$ taken with a negative sign and zonally averaged meridional winds $(v)$. From the zonally averaged continuity equation, the mass flux stream function, $\psi_{d}$, may be given by the equations,

$$
\begin{aligned}
& {[\bar{v}]=\frac{g}{2 \pi R \cos \phi} \frac{\partial \psi_{d}}{\partial p}} \\
& {[\bar{w}]=-\frac{g}{2 \pi R^{2} \cos \phi} \frac{\partial \psi_{d}}{\partial \phi}}
\end{aligned}
$$

where overbar represents the monthly mean and square bracket represents the zonal mean, $R$ is the mean radius of the earth, $\phi$ is the latitude and $g$ is the acceleration due to gravity. $\psi_{d}$ is calculated by assuming $\psi_{d}=0$ at the top of the atmosphere and integrating Eq. (1) downward to the surface. It may be noted that positive (negative) latitudinal gradient of $\psi_{d}$ would correspond to negative (positive) $[\bar{w}]$ or mean ascending (descending) motion. We use a positive sign for the stream function in the case of clockwise rotation and a negative sign for an anti-clockwise rotation (Oort and Yienger 1996). In Fig. 10, the mass flux stream functions are shown in contours.

As our primary interest is in the tropical Hadley circulation, we have confined ourselves to the region between $30^{\circ} \mathrm{S}$ and $30^{\circ} \mathrm{N}$. The anomalous Hadley circulations associated with the warm and cold decadal phases of inter-decadal oscillation are characterized by a single meridional cell, but of opposite signs. During the warm phase of the oscillation, there is ascending motion between the equator and $20^{\circ} \mathrm{S}$ and descending motion between the equator and $20^{\circ} \mathrm{N}$ while during the cold phase, there is a reversal in the circulation. How is it that the warm phase of the decadal/multi-decadal mode has zonal mean ascending motion in the Southern hemisphere and descending motion in the Northern hemisphere? This is understandable if we examine the SST pattern associated with the dominant decadal/multi-decadal variability (Fig. 4a). On zonally averaged sense, it tends to enhance SST in the SH between $15^{\circ} \mathrm{S}$ and $20^{\circ} \mathrm{S}$ resulting in stronger heat source and ascending 

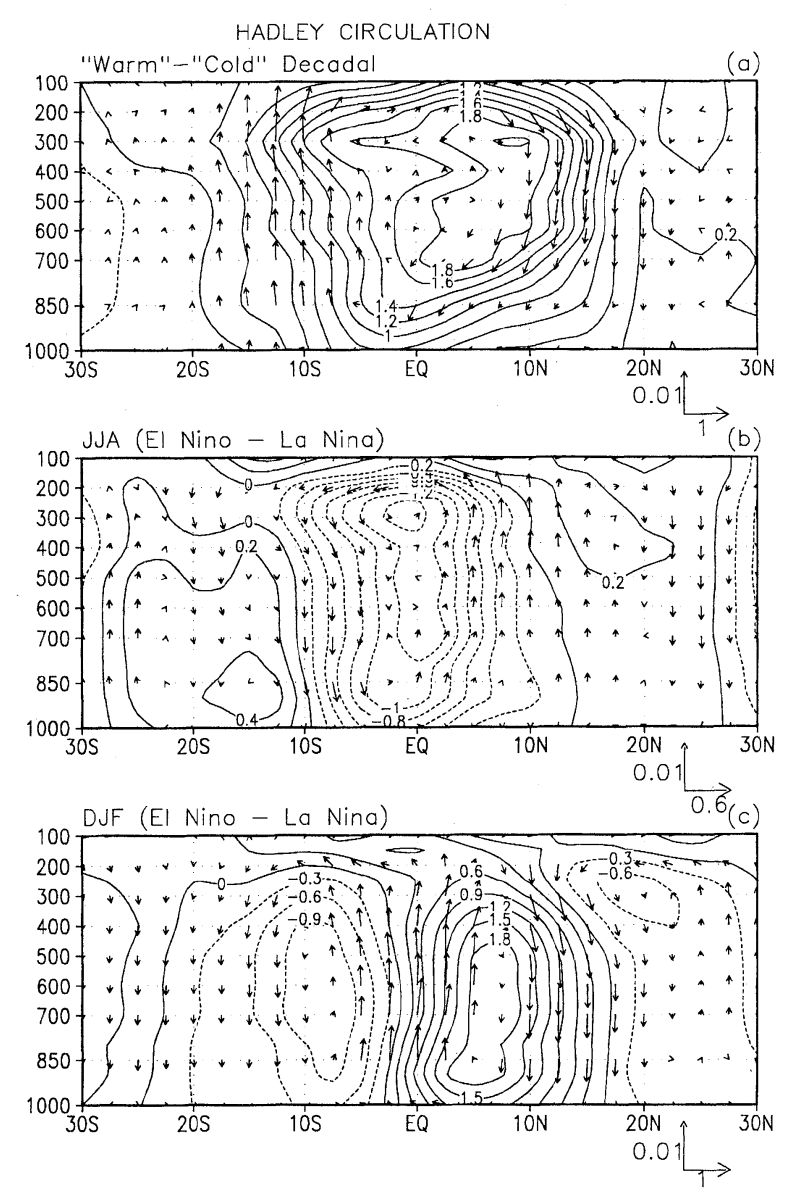

Fig. 10. (a) Same as in Fig. 9a but for mean boreal winter (DJF) ('warm'-'cold') composite Hadley circulation averaged over the whole globe. Unit vector for vertical velocities corresponds to $0.01 \mathrm{hPas}^{-1}$. (b) Same as Fig. 9b but for the boreal summer (JJA) Hadley circulation composite. Unit vector for velocities corresponds to $0.01 \mathrm{hPas}^{-1}$. (c) Same as Fig. $10 \mathrm{~b}$ but for boreal winter (DJF) Hadley circulation composite. Unit vector for vertical velocities corresponds to $0.01 \mathrm{hPas}^{-1}$.

motion there. The maximum $\psi_{d}$ value representing the strength of the Hadley circulation is centered around the equator during both phases. To represent the dominant inter-annual mode, boreal summer (JJA) and boreal winter (DJF) composite differences between El Nino and La Nina for anomalous inter-annual Hadley circulation are constructed and shown in Figs. 10b and 10c. The El Nino and La Nina years used in generating this composite are 1963, 1965, 1969, 1972, 1976, 1982, 1987, 1992, 1997 and 1964, 1968, 1971, 1973, 1983, 1988, 1996, respectively. The boreal winter composite constitutes of two cells with rising motion around the equator, and sinking motion between $10^{\circ}$ and $20^{\circ}$ latitude in both the hemispheres. A weak cell can be seen with ascent around $30^{\circ} \mathrm{N}$ and descent over $20^{\circ} \mathrm{N}$. The mass flux in the NH Hadley cell $\left(1.8 \times 10^{10} \mathrm{~kg} / \mathrm{s}\right)$ is twice as strong as that in the $\mathrm{SH}$ Hadley cell $\left(0.9 \times 10^{10} \mathrm{~kg} / \mathrm{s}\right)$. The boreal summer composite comprises of a single dominant cell $\left(1.3 \times 10^{10} \mathrm{~kg} / \mathrm{s}\right)$ with rising motion north of the equator and sinking motion south of the equator. The rising and sinking limbs extend to about $20^{\circ}$ latitude in both the hemispheres. A weak Ferrel cell is evident in the $\mathrm{SH}$.

It may be noted that the strength of the Hadley circulation associated with the multi-decadal variations are also comparable to those associated with inter-annual variations. The climate of any tropical belt at any instant may be obtained by a linear superposition of the decadal and inter-annual components. Thus, during a 'warm' phase of the multidecadal mode, the boreal summer Hadley cell associated with El Nino's (ascending motion in the northern tropics and descending motion in the southern tropics) is weakened, while that associated with La Nina (descending motion in northern tropics and ascending motion in the southern tropics) is strengthened. Similarly, during the cold phase of the multidecadal oscillation, the summer Hadley circulation associated with the El Nino's is strengthened while that associated with La Nina is weakened or neutralized. Therefore, during a warm phase of the multidecadal oscillation (such as one prevailing after 1976 till present), we may expect near normal summer precipitation during El Nino's, while enhanced precipitation in the $\mathrm{SH}$ and decreased precipitation in NH may be expected during La Nina's. During boreal winter (DJF), the multi-decadal Hadley cell remains similar to that during summer, while the inter-annual Hadley circulation associated with the El Nino's and La Nina's change which is evident from the DJF (El Nino-La Nina) composite shown in Fig. 10c. As a result, in the same phase of multi-decadal oscillation, decreased boreal winter precipitation is expected in the northern subtropics during an El Nino, while boreal winter precipitation is expected to be near normal during a La Nina. Similarly, during a warm phase of the multidecadal oscillation, El Nino will be associated with near normal southern sub-tropics precipitation while La Nina will be associated with enhanced southern sub-tropical precipitation.

\section{Summary}

Several decadal or multi-decadal climatic fluctuations have been identified in the tropics and extratropics from long records of surface data. However, the three-dimensional structure of these climate variations could not be studied as homogeneous global upper air data for a sufficiently long period of time was not available. Operational analysis archived at several operational weather predic- 
tion centers with records from early seventies suffered from artificial climate jumps due to a change in the analysis system and the forecast model. The NCEP/NCAR reanalysis project overcame some of these problems and produced a 50-year record of homogeneous global data set that became available recently. This 50-year reanalysis is used to estimate the three dimensional structure of two dominant decadal/multi-decadal oscillations of the tropical coupled ocean-atmosphere system.

The decadal/multi-decadal component has been separated from the inter-annual and other higher frequency oscillations using a spectral low pass filter. A combined EOF of the low-pass filtered surface and upper air data was carried out. Thus, the first two combined EOFs represent three dimensional structure of two dominant decadal/multidecadal modes of the coupled ocean-atmosphere system. The first CEOF appears to represent a pattern associated with trend and multi-decadal variability, while the second CEOF appears to represent the decadal variability. Both modes share some similarity with the ENSO-like inter-decadal variability in the Pacific studied earlier with surface data (ZWB). The second coupled mode represents the Atlantic dipole mode in the Atlantic basin, but is associated with significant SST variability in the tropical Pacific too. In fact, a regression of global SST with an index of ADV shows associated SST variability in the tropical Pacific similar to the SST CEOF2 pattern. We consider the second coupled mode to be a more general global version of the Atlantic Dipole mode.

Both modes show an approximate first baroclinic vertical structure over the tropics. As was shown with surface field (Zhang et al. 1997), the three dimensional patterns of the ENSO-like decadal/multidecadal oscillation are similar in some ways to those of its inter-annual counterpart with some notable differences. The Walker circulation associated with the ENSO-like multi-decadal mode has a wavenumber two structure in the zonal direction. The Walker circulation associated with the inter-annual ENSO mode is dominated by a wave number one east-west pattern. However, major ascending/descending limbs of decadal and inter-annual Walker circulations over the western Pacific $\left(100^{\circ} \mathrm{E}-140^{\circ} \mathrm{E}\right)$, the central Pacific $\left(170^{\circ} \mathrm{E}-130^{\circ} \mathrm{W}\right)$ and South America/the western Atlantic $\left(70^{\circ} \mathrm{W}-30^{\circ} \mathrm{W}\right)$ are nearly out of phase. They are in phase over the equatorial far eastern Pacific $\left(120^{\circ} \mathrm{W}-70^{\circ} \mathrm{W}\right)$, and in the Indian Ocean $\left(60^{\circ} \mathrm{E}-100^{\circ} \mathrm{E}\right)$. The ENSO-like multi-decadal mode and the inter-annual ENSO mode appear to be statistically independent of each other. Therefore, the superposition of the anomalies associated with the multi-decadal and inter-annual modes is likely to determine the regional climate in a particular year. In a warm eastern Pacific phase of the
ENSO-like multi-decadal mode, an El Nino is expected to be associated with near normal precipitation over the central Pacific, increased precipitation over the eastern Pacific while intensifying drought conditions over Indonesia and northern Australia. During the opposite phase of the ENSO-like multidecadal oscillation, however, an El Nino is expected to have increased central Pacific precipitation and decreased eastern Pacific precipitation. Similarly, it is also shown that the boreal summer Hadley circulation anomalies associated with the inter-decadal and the inter-annual modes are similar in meridional structure as well as in magnitude. However, the two meridional circulations tend to be out of phase during boreal summer. As a result, during a 'warm' phase of the inter-decadal oscillation, we may expect near normal $\mathrm{NH}$ summer precipitation during El Nino's, while enhanced precipitation in the $\mathrm{SH}$ and decreased precipitation in NH may be expected during La Nina's. The effects are expected to reverse during the 'cold' phase of the inter-decadal oscillation.

\section{Acknowledgments}

The work is partially supported by a grant from the Department of Ocean Development, Government of India. Computations were carried out at the Super Computer Education and Research Center, Indian Institute of Science. The authors are greatful to two anonymous referees for comments on the original manuscript that led to improvement of the manuscript.

\section{References}

Bassnett, T.A. and D.E. Parker, 1997: Development of global sea level pressure data set GMSLP2. Climate Research Technical Note- 79, 54pp (Available from Hadley Center, Meteorological Office, London Road, Bracknell, Berkshire, RG1225Y, UK).

Carton, J.A., X. Cao, B.S. Giese and A. da Silva, 1996: Decadal and inter-annual SST variability in the tropical Atlantic. J. Phy. Oceanogr., 26, 1165-1175.

Houghton, R.W. and Y.M. Tourre, 1992: Characteristics of low frequency sea surface temperature fluctuations in the tropical Atlantic. J. Climate, 5, 765-771.

Kachi, M. and T. Nitta, 1997: Decadal variations of the global ocean atmosphere system. J. Meteor. Soc. Japan, 75, 657-675.

Kalnay, E., M. Kanamitsu, R. Kistler, W. Collins, D. Deaven, L. Gandin, M. Iredell, S. Saha, G. White, J. Woollen, Y. Zhu, M. Chelliah, W. Ebisuzaki, W. Higgins, J. Janowiak, K.C. Mo, C. Ropelewski, J. Wang, A. Leetma, R. Reynolds, R. Jenne and D. Joseph, 1996: The NCEP/NCAR 40 year Reanalysis Project. Bull. Amer. Meteor. Soc., 77, 437-471.

Kaplan, A., Y. Kushnir, M.A. Cane and M.B. Blumenthal, 1997: Reduced space optimal analysis of historical data sets: 136 years of Atlantic sea surface temperatures. J. Geophys. Res., 102C, 2783527860 . 
Mehta, V.M., 1998: Variability of the tropical ocean surface temperatures at decadal - multi-decadal time scales, Part I: The Atlantic ocean. J. Climate, 11, 2351-2375.

Moura, A.D. and J. Shukla, 1981: On the dynamics of droughts in NE Brazil: observation, theory and numerical experiments with a GCM. J. Atmos. Sci., 38, 2653-2675.

Oort, A.H. and J.J. Yienger, 1996: Observed interannual variability in the Hadley circulation and its connection with ENSO. J. Climate, 9, 2751-2767.

Reynolds, R.W. and T.M. Smith, 1994: Improved global sea surface temperature analysis using optimum interpolation. J. Climate, 7, 929-948.

Nigam, S. and H. Shen, 1993: Structure of oceanic and atmospheric low frequency variability over the tropical Pacific and Indian Oceans. Part 1: COADS observations. J. Climate, 6, 657-676.

North, G.R., T.L. Bell and R.F. Cahalan, 1982: Sampling errors in the estimation of Empirical Orthogonal Functions. Mon. Wea. Rev., 110, 699-706.
Servain, J., 1991: Simple climatic indices for the tropical Atlantic ocean and some applications. J. Geophys. Res., 96, 15135-15146.

Trenberth, K.E. and J.W. Hurrell, 1994: Decadal oceanatmosphere variations in the Pacific. Clim. Dyn., 9, 303-319.

White, W.B. and D.R. Cayan, 1998: Quasiperiodicity and global symmetries in interdecadal upper ocean temperature variability. J. Geophys. Res., 103, 21335-21354.

White, W.B., J. Lean, D.R. Cayan and M.D. Dettinger, 1997: Response of global upper ocean temperature to changing solar irradiance. J. Geophys. Res., 102, 3255-3266.

Woodruff, S., R. Slutz, R. Jenne and P. Steurer, 1987: A Comprehensive Ocean Atmosphere Data Set. Bull. Amer. Meteor. Soc., 68, 1239-1250.

Zhang, Y., J.M. Wallace and D.S. Battisti, 1997: ENSO like inter-decadal variability: 1900-1993. J. Climate, 10, 1004-1019.

\section{熱帯における海洋・大気結合の 10 年・数 10 年変動モード}

\section{B.N. Goswami • Maru Anna Thomas}

(Center for Atmospheric and Oceanic Sciences, Indian Institute of Science, India)

\section{NCEP/NCAR の再解析プロジェクトによる 50 年間 (1949-98 年) にわたる均質な高層デー夕、海面水} 温㧍よび海面気圧のデータを使用して、熱帯において卓越する 10 年と数 10 年、 2 つの変動の三次元構造 を明らかにした。これらのグローバルな三次元モードによって、これまで地上データのみによって解明さ れてきた 10 年・数 10 年変動をより包括的に示すことができた。鉛直方向には、両モードともおおむね第 一傾圧モード構造をもっている。数 10 年変動に伴うウオーカ一循環は、東西方向に波数 2 の構造を示す。 数 10 年変動に伴うハドレー循環とウ オーカー循環の主要な上昇および下降運動の大きさは、年々変動と 同程度である。これらの長周期変動に伴うグローバルな大気大循環によって、地域的な気候の年々変動が 変調を受けるメカニズムを考察した。 